\title{
A communicative and cognitive approach to teaching monologue communication to foreign students in the educational and professional sphere
}

\author{
Olga Voskerchyan ${ }^{1, *}$ and Larisa Lepichova ${ }^{1}$ \\ ${ }^{1}$ Don State Technichal University, Gagarin sq., 1, 344003 Rostov-on-Don, Russia
}

\begin{abstract}
The article discusses the issue of the unit of learning/mastering of foreign students to a scientific monologue as one of the types of communicative-cognitive activity. In the mainstream of the communicativecognitive approach, the content of the concept of a unit of learning/assimilation is formulated, the requirements and functions of this methodological category are described, the parameters of methodological modeling are indicated.
\end{abstract}

\section{Introdution}

The communicative and cognitive activity of foreign students in the study of the Russian language and subjects according to the profile of the specialty assumes that an adult student possesses a set of knowledge inherent in a particular culture, as well as knowledge of a universal nature. The acquisition of new knowledge is included in the cognitive system of students. The means of educational activity are intellectual actions (mental operations); speech actions; sign and verbal means, in the form of which the content of an academic discipline is mastered, individual experience is structured.

The modern methodology of teaching Russian to foreign students reflects both communicative and cognitive approaches [1-9]. The appeal only to the communicative or only to the cognitive aspects of the study of speech activity cannot adequately reflect the mechanism underlying the teaching of a foreign language. The communicative-cognitive approach to speech activity opens up ample opportunities to see in teaching speech in a foreign language its connection with human intelligence, mental and cognitive processes, those structures and mechanisms that underlie the receipt, storage and transmission of information. This approach allows you to connect the data of the sciences about language, society and man and use them for methodological purposes [10-16].

A conscious and purposeful appeal to the cognitive base of teaching a foreign language as a method of communication puts forward the task of modeling a unit of learning / mastering communication in a foreign language.

\footnotetext{
* Corresponding author: olga3212321@gmail.com
} 


\section{Problem Statement}

The relevance of the proposed work is due to the need to find a method for modeling the unit of learning / assimilation, which contributes to the development of speech-thinking activity within the framework of Russian as a foreign language [17].

When discussing the problem of the unit of learning / assimilation (UL/UA) from the need to take into account two different, but closely interrelated aspects of the problem:

- comprehension of the very concept of UL/UA as a methodological category and requirements for it, dictated by the approach to learning as a communicative-cognitive activity;

- understanding the nature and specific content of this concept in relation to the task of teaching a certain type of speech activity.

Methodical modeling is coupled with the need to discuss the problem of the unit of learning / assimilation in the formation of the ability to communicate in the foreign language being studied. This problem was investigated by us in relation to teaching monologue speech in the educational and professional sphere.

\section{Main Part}

When discussing the concept of UL/UA, we proceed from a number of general theoretical provisions:

- it is a methodological model that reflects the most essential characteristics of the ability to a certain type of speech activity, formed through the UL/UA;

- it should be communicative, which we understand 1) as its ability to correlate with a real communicative act arising in a certain context of students' cognitive activity in accordance with the real needs and goals of communication; 2) its methodological purpose is to form the skills required in real conditions of communication.

- it should be differentiated depending on the type of speech activity and, in a methodically "prepared" form, reflect the specifics of this type and form of communication; differentiation of UL /UA, depending on the type of speech activity that students master, involves taking into account the specifics of the process of generating speech;

- it should reflect the dynamics of the process of forming and formulating thoughts by means of the studied language in the form of speech being mastered. In addition, and this is the main thing, the UL /UA is methodologically expedient and clearly demonstrates the progressive development of communicative abilities in a specific type of speech activity;

- it should be comprehensive. One can speak about a unit of instruction in terms of dialectical categories "part-whole". In other words, speech action as UL/UA is a complex of educational actions with linguistic material, subject to assimilation, in the process of which the student masters a certain type of ability to solve communicative-cognitive communication tasks with foreign language means;

- as a methodological model of a real process and the ability to communicate, it is a hierarchically organized system, all the components of which are connected and represent the main features of a particular communication process, as well as the progressive complication of skills as a measure of the abilities acquired in the learning process.

Summarizing the above, we offer the following definition of the concept under discussion: $U L / U A$ is a methodological model of a dynamic system of hierarchically organized speech actions; each level of this hierarchy in different ways, but in interconnection, represents the main psycholinguistic characteristics of the type of speech activity that students master.

As a methodological category, the UL/UA performs a number of functions in the educational process: 
- The representative function of the UL/UA is that at each hierarchical level, the components of speech activity to be mastered are presented in a complex way for the actual understanding by students. We mean foreign language means (phonetic, lexical, grammatical), the rules for their use, typed speech works (texts, statements), created to solve certain communicative and cognitive communication problems. These objects of assimilation should be represented by appropriate units of presentation. The units of presentation are speech samples of typified products of speech activity (utterance, text), semantic-syntactic structures for constructing sentences, logical-syntactic schemes for constructing super phrasal units, formulations of communication tasks, rules-instructions for performing educational actions, action algorithms, etc. In other words, we are raising the question of the complex presentation of the UL/UA by presentation units of different nature. A comprehensive presentation of the unit of learning / assimilation allows you to take into account the personal characteristics of students: their cognitive preferences, learning styles, past experience of educational and cognitive activity.

- Determining function. The UL/UA system, like each level unit, due to its main communicative characteristics, presupposes forms and sequence of work corresponding to its quality, ensuring the assimilation of educational material and actions with it. Based on the communicative essence of UL/UA, we can say that exercises, tasks should correspond to those phases that determine the structure of any act of communicativecognitive activity. We believe that the organization of educational activities in the form of exercises is a derivative of the above-mentioned function, since the sequence of training activities is determined by the choice of the UL/UA itself.

- Controlling function. UL/UA serves as a measure of measurement the communicative abilities of students. This function is to help the teacher and student identify the achieved level of language proficiency and determine in which link and what needs improvement. The complex nature of UL/UA allows us to speak about the possibility of various objects of assimilation control. We can talk about objects of aspect (operations - components of UL/UA) and complex control of mastering speech action of a certain level. At each level of UL/UA, it is the quality of the performance of a speech action that objectifies the communicative skills acquired by students. The hierarchical organization of the UL/UA system presupposes the cyclical nature of the current control of language acquisition as a means of communication. In this case, we can raise the question of the differentiated activity of the consciousness of students at one or another level of UL/UA, i.e. to identify components that are actually perceived, consciously controlled and components brought to automatism. In the process of learning / assimilation, this aspect of activity is dynamic, since what is consciously controlled at a lower level is then transferred to the level of automatism.

The above general theoretical propositions serve as our starting points. We associate the specification of these provisions with the consideration of a scientific monologue as one of the forms of communicative educational and cognitive activity.

As an object of analysis, we were primarily interested in educational and professional communication, organized, regulated and directed by the teacher. It is carried out during a practical lesson, exam, consultation, as well as during the work of hobby groups in various scientific disciplines, holding student conferences.

Communicative interaction in these conditions, as is clear from observations, is thematically organized communication. A monologue on a scientific topic was prepared by the educational and cognitive activities of students. This is, first of all, the reproduction of the obtained scientific knowledge. At the same time, it requires every time a verbal improvisation, the form and volume of which varies considerably depending on the conditions of communication. It occurs in certain communicative conditions and may be due to: 
- a practical need for students to demonstrate received knowledge;

- desire to make a presentation on a scientific topic;

- the need to take part in the discussion of a scientific problem.

The ability to transfer the acquired knowledge in accordance with the conditions, goals of the communicative act; the speaker's consideration of social factors of communication who, what, to whom, why - is an indicator of the competent possession of this form of speech communication.

Speaking in a monologue consists of a sequence of speech actions that are characterized by an independent, but intermediate in relation to all activities, a communicative goal, or a communicative task. The performance of each speech action is conditioned, in addition to the goal, by the preceding actions, the setting of the action and the result to be achieved. Unlike dialogue, speech actions in a monologue form of communication are weakly dependent on the partner's speech actions. They represent a semantically autonomous, thematically purposeful, ordered sequence of speech actions, conditioned by the logic of the development of thought.

Considering the general psychological features of a monologue when substantiating the concept of "UL/UA system", we raise the question of the methodologically expedient division of a monologue as a single and normally indivisible process of forming and formulating thought. When proposing the UL/UA hierarchy, it is legitimate to look for the correlation of a speech action with its subject - a thought, which should be formulated by means and methods of the language being studied. The requirement of dynamism implies that speech actions as an UL/UA should differ in the amount of content.

As they move from one level of UL/UA to another, students learn to objectify in speech the increasingly complex connections between objects of reality. Expansion of the subjectsemantic content of speech action as UL/UA develops in students the mechanisms of anticipatory synthesis in the process of speaking, the volume of long-term and operational capabilities of short-term memory.

Modeling the UL/UA system for the formation of the ability to implement a monologue form of communication, it is natural to proceed from the following. Making a speech action, the speaker objectifies the cognitive-logical process of reflecting the object of reality in accordance with the conditions and task of communication. The act of predication (referring the content of a statement to reality), being a universal way of correlating concepts, is carried out in a sentence and is expressed by a predicative connection. In addition to the main connection, there are other types of semantic connections. These are concretization, expansion, addition, explanation, clarification, generalization, etc. They correlate with additional, definitive, adverbial syntactic connections. In speech action, the object of reality can be represented:

- at the level of a single predicative connection;

- at the level of the main predicative and additional semantic connection;

- to disclose an object, it is necessary to inform facts and establish semantic connections between them, which will require not one, but several speech actions.

The foregoing suggests the need for a three-tier UL/UA system. The unit of the lowest level is a speech action in which a single fact related to a given subject of speech is reported and one predicative connection is objectified. UL/UA of this level will be called a simple speech action. The unit of the next level will be called a complex speech action, assuming that it communicates about some fact and, in addition to the main (single) connection between concepts, additional semantic connections to it are objectified. The UL/UA of the highest level should correlate with the act of monologue communication, i.e. to represent an orderly following one after another speech actions, through which the idea of a certain object in its connections and relations with others is quite fully formulated, a set of information about a 
given subject of speech is communicated. The UL/UA of a given level will be called a macro action, or a block of speech actions.

Thus, the methodological understanding of the psycholinguistic features of a monologue as a special type of speaking made it possible to assume the legitimacy of using the threelevel UL/UA system, building their hierarchy according to the degree of complexity and the volume of subject-semantic content.

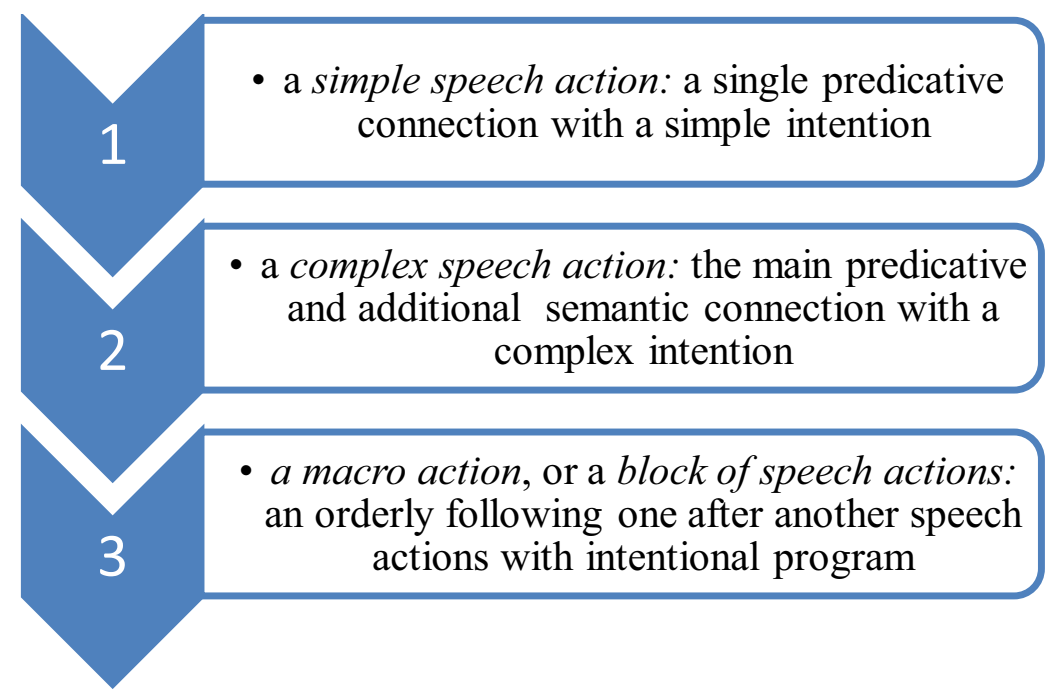

Fig.1. Three-level UL/UA system hierarchy

Methodological comprehension of the relevance of linguistic and psycholinguistic features of the monologue form of communication when describing the UL/UA hierarchy for its implementation leads to the idea that:

- it should differ not only in the subject-semantic plan, but also in the plan of expression;

- in terms of expression, it is necessary to take into account the nature of the nomination and predication;

- and also the homomorphism of the content plan and the plan of expression.

At each level of the UL/UA, students carry out educational actions and master the means and ways of formulating thoughts in a foreign language. With the help of educational actions, students master the necessary speech operations, which for a certain time act as independent learning tasks and an object of assimilation. It is important to emphasize that all types of tasks that work out certain educational actions should be of a communicative nature. Being training (linguistic at its core), they should be aimed at students' comprehension of the communicative task and the content of the speech act, and not its form. Therefore, such formulations of tasks are necessary, which determine the focus of attention on the communicative content of the utterance, set the parameters of the error-free choice of the form in this situation of the act of speech. Let us consider examples of tasks:

1. Read the individual phrases and identify the topic to which they relate. Compose a message from these phrases on the topic.... Remember: a) first comes the main thesis, then its specification, addition, example; b) do not call the subject of speech by the same word.

2. Expand thesis.... Remember to give an explanation; introduce the necessary concepts; give examples.

3. You have come across a message fragment. Determine the subject of the message and what part of the message the given fragment is. Recover the entire message. 
4. Comment on the proposed scheme. (A graph of denotations is given).

5. Suggest several options for a message on the topic ...:

a) you are responding to the instructor and must demonstrate knowledge of the basic concepts;

b) you tell this topic to a friend who was not in class;

c) you should link this topic with a more general problem, for example, ...;

d) you are speaking at a meeting of a student conference and you need increase the attention of the audience.

Guided by the above theoretical provisions, the authors create teaching aids and didactic materials, including tasks that allow you to purposefully form all types of competencies and develop the ability of independent activity.

\section{Conclusion}

Any training, including teaching a foreign language, must be organized as a process of active, purposeful, motivated formation of students' knowledge and competencies for mastering the chosen specialty. The communicative-cognitive paradigm in the methodology of teaching foreign languages, and Russian as a foreign language in particular, is based on a number of provisions. First, students are active participants in the learning process, whose individual interests and characteristics must be taken into account. Secondly, the development of thinking and mechanisms of foreign language speech thinking is an essential part of the educational process; the educational and scientific sphere of activity involves the involvement of students in the active process of learning the essence of the phenomena being studied, when conditions are created for the realization of personal guidelines and professional goals. And most importantly, the formation of communicative competence among foreign students means the ability to solve communication problems in the field of scientific (educational and scientific) communication.

Methodological modeling of various levels of ability to formulate a thought requires closer attention to the process of speech generation and the search for units of learning / assimilation that are adequate to the type of speech activity that students master. The concept of the unit of learning / assimilation proposed by us reflects the specifics of the process of generating speech: from meaning to ways of expressing it, i.e. to the production of an utterance of a certain level.

\section{References}

1. Ya.Kh. Abbas, Cognitive-communicative approach in the system of teaching the Russian language for foreign students in the absence of a language environment, Language and Culture 47, 301-312 (2019) https://cyberleninka.ru/article/n/kognitivnokommunikativnyy-podhod-v-sisteme-prepodavaniya-russkogo-yazyka-dlyainostrannyh-studentov-v-usloviyah-otsutstviya-yazykovoy (Last accessed 2021/01/22)

2. M.E. Bukeeva, Formation of intercultural communicative competence in teaching a foreign language in a non-linguistic university, Izvestia of the Volgograd State Pedagogical University 2(145), 101-106

https://cyberleninka.ru/article/n/formirovanie-mezhkulturnoy-kommunikativnoykompetentnosti-pri-obuchenii-inostrannomu-yazyku-v-neyazykovom-vuze accessed 2021/01/25)

3. E.V. Busurina, V.D. Gorbenko, Actualization of communication spheres in professionally oriented teaching of Russian as a foreign language, Bulletin of the Moscow State Regional University. Series: Pedagogy 2, 66-76 (2020) 
https://cyberleninka.ru/article/n/aktualizatsiya-sfer-obscheniya-v-professinalnoorientirovannom-obuchenii-russkomu-yazyku-kak-inostrannomu (Last accessed 2021/01/25)

4. S.E. Grigorenko, I.V. Sagalaeva, Basic principles and criteria of communicativecognitive teaching of a foreign language, Pedagogical education in Russia 8, 261-265 (2014) https://cyberleninka.ru/article/n/osnovnye-polozheniya-i-kriteriikommunikativno-kognitivnogo-obucheniya-inostrannomu-yazyku (Last accessed 2021/01/25)

5. T.N. Korzh, Principles of foreign language professionally oriented teaching from the standpoint of the cognitive-communicative approach, Questions of teaching methods at the university 20, 37-45 (2017) https://cyberleninka.ru/article/n/printsipyinoyazychnogo-professionalno-orientirovannogo-obucheniya-s-pozitsiy-kognitivnokommunikativnogo-podhoda

6. S.V. Mayboroda, A communicative-cognitive approach in teaching coherent speech to foreign medical students, Pedagogy of higher education 1(4), 66-68 (2016)

7. N.A. Malysheva, General didactic principles of communicative-cognitive teaching of foreign students-philologists the Russian language in the process of mastering linguistic features, Innovative $\quad$ Science 12-2, 237-239 https://cyberleninka.ru/article/n/obschedidakticheskie-printsipy-kommunikativnokognitivnogo-obucheniya-inostrannyh-studentov-filologov-russkomu-yazyku-vprotsesse (Last accessed 2021/01/25)

8. I.S. Milovanova, Cognitive approach in the methodological organization of the educational process (on the example of teaching Russian pronunciation to foreign students), Multilingualism and transcultural practices 1, 18-21 (2013) https://cyberleninka.ru/article/n/kognitivnyy-podhod-v-metodicheskoy-organizatsiiuchebnogo-protsessa-na-primere-obucheniya-russkomu-proiznosheniyu-inostrannyh

9. D. Newby, The role of theory in pedagogical grammar: A Cognitive + Communicative approach, Eurasian Journal of Applied Linguistics 1(2), 13-34 (2015)

10. M. Salomova, Communicative approach to teaching foreign languages, Proceeding of The ICECRS 3, $1-3 \quad$ (2019) https://press.umsida.ac.id/index.php/icecrs/article/view/265/129?download=pdf

11. N.S. Nurieva, On the question of the communicative-cognitive approach in teaching foreign languages in a non-linguistic university, Bulletin of the Russian State University for the Humanities. Series "Psychology. Pedagogy. Education". 3, 32-40 (2019) https://cyberleninka.ru/article/n/k-voprosu-o-kommunikativno-kognitivnom-podhodev-obuchenii-inostrannym-yazykam-v-neyazykovom-vuze

12. V.S. Podoprigora, Cognitive and Behavioral Approaches to Teaching Russian as a Foreign Language, Molodiy Vchenii 6(33), 376-379 (2016)

13. V.V. Reshetnikova, Teaching the communicative behavior of foreign students in the Russian language classes at a non-linguistic university, Eurasian Union of Scientists 74(16), 112-115. (2015) https://cyberleninka.ru/article/n/obuchenie-kommunikativnomupovedeniyu-inostrannyh-uchaschihsya-na-zanyatiyah-po-russkomu-yazyku-vneyazykovom-vuze (Last accessed 2021/01/25)

14. N.P. Shulgina, N.P. Bugaenko, On the issue of creating a cognitive model of teaching Russian as a foreign language, News of the South-West State University. Series: Linguistics and Pedagogy 3, 68-73 (2015)

15. M. Salomova, Communicative approach to teaching foreign languages, Proceeding of The ICECRS 3, 1-3 (2019) 
16. E.M. Baeva, Communicative approach in teaching Russian as a foreign language: new resources, new activities. Communication Studies, 2(12), 89-95 (2017) https://cyberleninka.ru/article/n/communicative-approach-in-teaching-russianas-a-foreign-language-new-resources-new-activities/viewer (Last accessed 2021/02/02)

17. O.M. Voskerchyan, Communicative-cognitive paradigm in the methodology of teaching foreign languages: unit of study, 147 (Publishing Center of DSTU, 2010) 